Discussion Paper No. 07-074

\title{
Determinants of Child Care Participation
}

Katja Coneus, Kathrin Goeggel, and Grit Muehler

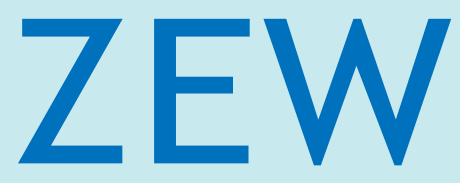

Zentrum für Europäische Wirtschaftsforschung $\mathrm{GmbH}$

Centre for European

Economic Research 


\section{Non-technical summary}

Over the last twenty years, the proportion of children experiencing institutional child care has grown steadily. This development is clearly related to increasing female labor market participation as the decision to use child care outside the home is strongly connected to mothers' decision to work after childbirth. In West Germany, child care use for children aged three to seven is still low in comparison to other Western European countries. The aim of the study is thus to investigate the main factors that drive the decision for institutional child care in West Germany using an estimation approach which explicitly accounts for the simultaneity in mothers' decision to work and the decision for child care. Our results confirm that the labor market status of the mother is an important predictor for the fact whether the child is in institutional care or not. First-born children living in Western Germany have a higher probability to attend institutional care if their mothers increase their actual weekly working time. Parents might thus consider child care as an alternative when the mother wants or needs to work. Furthermore, we can show that estimating the probability to attend child care without accounting for the simultaneity in the work and care decisions leads to a substantial underestimation of the effect. 
Discussion Paper No. 07-074

\title{
Determinants of Child Care Participation
}

\author{
Katja Coneus, Kathrin Goeggel, \\ and Grit Muehler
}

Download this ZEW Discussion Paper from our ftp server:

ftp://ftp.zew.de/pub/zew-docs/dp/dp07074.pdf

Die Discussion Papers dienen einer möglichst schnellen Verbreitung von neueren Forschungsarbeiten des ZEW. Die Beiträge liegen in alleiniger Verantwortung der Autoren und stellen nicht notwendigerweise die Meinung des ZEW dar.

Discussion Papers are intended to make results of ZEW research promptly available to other economists in order to encourage discussion and suggestions for revisions. The authors are solely responsible for the contents which do not necessarily represent the opinion of the ZEW. 


\title{
Determinants of Child Care Participation*
}

\author{
Katja Coneus, Kathrin Goeggel, Grit Muehler
}

November 2007

\begin{abstract}
When estimating the determinants of child care participation, the simultaneity in mothers' decision to work and in the decision to use child care is a major challenge. In this study, we provide evidence on the determinants of institutional child care use accounting for the endogeneity of mothers' labor supply by applying an instrumental variables approach. This endogeneity has been neglected in studies on this issue so far, even though the decision to use child care outside the home is strongly connected to mothers' decision to work after childbirth and vice versa. Based on the German Socio-economic Panel (GSOEP) from 1989-2006 we show that children living in Western Germany have a higher probability to attend institutional care if their mothers increase their actual weekly working time. Estimating the determining factors of child care participation without correcting for simultaneity underestimates the influence of maternal working time by more than a half.
\end{abstract}

Keywords: child care choice, kindergarten attendance, maternal employment JEL-classification: I21, J13, J22

\footnotetext{
${ }^{*}$ Centre for European Economic Research (ZEW), Mannheim. Corresponding address: L7, 1, 68161 Mannheim, Katja Coneus: coneus@zew.de, Kathrin Goeggel: goeggel@zew.de, Grit Muehler: muehler@zew.de. We thank Andreas Ammermueller, Irene Bertschek, Holger Bonin, Alfred Garloff, Anja Heinze, Maresa Sprietsma, seminar participants at the ZEW and the LoWER Network Conference on Gender in September 2007 for helpful comments. All remaining errors are ours.
} 


\section{Introduction}

The decision to use child care outside the home is strongly connected to mother's decision to work after childbirth. As child-rearing is traditionally confined to women their labor market participation determines a family's demand for out-of-home care and is a widely cited reason for growing child care participation rates (e.g. OECD, 2006). Apart from using non-parental care to allow women to combine work and family responsibilities, a growing awareness for the importance of preschool education is a second reason for the increase in the use of institutional child care. Social policy emphasizes the child's right for development and education. Hence, attitudes of parents towards extra domestic child care have changed over time and made kindergarten to an institution which provides not only care but also contributes to education and socialization of young children today. The question of how to educate children best is thus broadly debated in public nowadays.

Over the last twenty years, the proportion of non-parental child care has grown steadily (Bien, Rauschenbach, and Riedel, 2006; OECD, 2006). This development is clearly related to increasing female labor market participation. In Germany, the employment ratio of 20- to 44-year-old women rose from around 60 percent in 1980 to almost 80 percent in 2006 (Eurostat 2007). Considering mothers only, labor supply has also constantly risen over the last two decades. However, the employment rate of mothers in Germany is very low compared to other countries. In the year of birth employment of mothers reduces by almost 60 percentage points in Germany compared to e.g. 30 percentage points in the U.K. or 16 percentage points in Denmark (Geyer and Steiner, 2007). The decision to return to the labor market after child birth is determined by several factors. Geyer and Steiner (2007) show positive state dependence between female employment before and after child birth. In addition, Bender, Kohlmann, and Lang (2003) find that younger cohorts as well as mothers with larger experience and better occupational status are more likely to restart working after child birth. Furthermore, the decision to reenter the labor market is intertwined with the level of provision of institutional care. Some studies give evidence that the availability and quality of child care infrastructure influence the return decision in a way that mothers are more likely to return to the labor market if there is an adequate child care infrastructure (Buechel and Spiess, 2002; Djurdjevic, 2005).

As early childhood education and care services in Germany are mostly publicly provided, institutional child care is the dominant child care setting for German children. The type of center-based care and the share of children attending it, depend mainly on the child's age. One institution is caring for infants and toddlers up to the age of three ("Kinderkrippe") and another for children from three to six/seven ("Kindergarten"). ${ }^{1}$ The attendance of each of these institutions is up to parents' decisions and not mandatory for the child. As far as statistical data can show, only few German children are cared for in other

\footnotetext{
${ }^{1}$ Recently this separation into age specific institutions is sometimes given up in favor of age-mixed child care settings ("Kindertagesstätten") which cover the whole age range.
} 
unlicensed and informal settings. In Germany child care is largely subsidized and mostly provided by public and non-profit institutions. Parental costs for child care are low in international comparison and fee structure accounts for parental income. As maternity leave was extended to a duration of three years in 1992 the majority of children starts kindergarten at the age of three. Additionally, a change in law in 1996 allowed parents to legally claim access to kindergarten when their child turns that age until it enters school. Hence, parents are not constrained when requesting a half-time slot for their child which is three years or older. Consequently, that is what most German parents do (Hank and Kreyenfeld, 2003). However, parents with children under age three and parents in need for a full-time slot face supply side restrictions.

In this study we investigate the main factors that drive the decision for institutional child care in West Germany. Previous economic literature exploring the child care choices of parents (e.g. Peyton, Jacobs, O'Brien, and Roy, 2001; Johansen, Leibowitz, and Waite, 1996), separated for different types of family backgrounds (e.g. for low income families, Henly and Lyons, 2000), and for different age groups of children (e.g. for infant care choices, Seo, 2003; Pungello and Kurtz-Costes, 1999). As child care choice is largely dependent on a country's institutional and political framework most analysis are country specific (e.g. for Italy see Del Boca, Locatelli, and Vuri (2005), e.g. for the U.S. and Canada see Michalopoulos and Robins (2002)). For Germany, Ondrich and Spiess (1998) calculate hazard rates for market and home care. They show that households with fewer children and working mothers have a higher demand for market care than for home care. Focussing on the enrolment to institutional care, there are two main studies for Germany analyzing the impact of parental socio-economic background on the use of institutional child care. Based on the German Socio-Economic Panel (GSOEP) Spiess, Buechel, and Frick (2002) analyze the effect of different socio-economic factors on the probability of using institutional child care for kindergarten-aged children. They find a significantly higher probability for the use of kindergarten for elder children with single or working mothers and from wealthier families. By using German census data Kreyenfeld (2004) can enlarge the analysis and includes foreigners in the multivariate analysis. The higher number of observations also allows her to separately estimate the use of institutional care in the different age groups $(1-3,4-7,7-10)$. Her results are somewhat similar to what Spiess, Buechel, and Frick (2002) found. Immigrants are less likely to go to kindergarten, children from mothers with high educational background have a higher probability to attend kindergarten.

The main goal of our study is to disentangle the effect of a mother's decision to work on the decision for institutional child care in West Germany. In contrast to other studies for Germany, we explicitly take into account that a mother's labor market decision affects simultaneously the decision for institutional child care. To solve the endogeneity problem we use a binary response model approach with one continuous endogenous regressor. Since the conditions for identification are the same as those in the usual simultaneous equation 
model, the actual working time of the mother two years before the birth of the first child serves as an instrument for actual maternal labor supply.

Our results show that children living in West Germany have a higher probability to attend institutional care if the mother increases her weekly working time. The influence of the hours worked in the binary response model with one continuous endogenous regressor is more than twice as large as predicted by the probit model. Thus, estimating the determining factors of child care participation without correcting for simultaneity underestimates the influence of maternal working time substantially.

The remainder of this paper is organized as follows. The estimation strategy is outlined in Section 2. Section 3 summarizes data, samples and explanatory variables. Section 4 presents results and discussion and Section 5 concludes.

\section{Econometric Framework}

We estimate a probit model with one continuous endogenous regressor to assess the probability for a child to attend child care. The choice problem is then described in the latent variable model (equation (1) and equation (2)).

$$
\begin{aligned}
& y^{*}=\beta_{0}+\beta_{1} \text { worktime }+\beta_{2} \text { educm }+\beta_{3} \text { sibl }+\beta_{4} \text { age }+\beta_{5} \text { agem } \\
& +\beta_{6} \text { nat }+\beta_{7} \text { citysize }+\beta_{8} \text { state }+\beta_{9} \text { years }+u \\
& Y= \begin{cases}1 & \text { if } y^{*}>0 \\
0 & \text { if } y^{*} \leq 0\end{cases} \\
& \text { worktime }=\alpha_{0}+\alpha_{1} \text { worktime }_{t-2}+\alpha_{2} \text { educm }+\alpha_{3} \text { sibl }+\alpha_{4} \text { age } \text { a }_{c}+\alpha_{5} \text { agem } \\
& +\alpha_{6} \text { nat }+\alpha_{7} \text { citysize }+\alpha_{8} \text { state }+\alpha_{9} \text { years }+v
\end{aligned}
$$

The indicator variable $Y$ describes CHILD CARE attendance and turns 1 if the child attends child care and 0 otherwise. The latent (unobserved) continuous variable $y^{*}$ denotes hours of institutional child care demanded by the mother. Our main variable of interest is the actual working time of the mother. Other important parental determinants are education, age and nationality and the family structure. We further control for the number of siblings in the household, the age of the child, city size (Gemeindegroesse) and federal state effects (Laender). Year effects are included to control for changes in labor supply and for differences in the labor market situation. All variables are described in Table A.1. Under the assumption of an independent and normally distributed error term we are interested in the conditional expectation function. But the use of institutional child 
care and mothers' decision to return to the labor market after child birth constitutes an interdependent decision making process. In econometric terms, this means that there is a feedback relationship between both variables causing probit estimates of the probability to participate in institutional child care to be biased. As simultaneity is one source of endogeneity, one solution to that problem is to employ instrumental variables. A suitable instrument must fulfill two conditions. First, it needs to be correlated with the actual working time of the mother which is the endogenous variable. Second, it may not affect current child care attendance except through the endogenous variable.

Our source of exogenous variation in the maternal labor supply is the actual working time of the mother two years before child birth of the first-born child. We focus on the first-born children in our analysis as we do not want to create multiple observations for one mother using the same instrument. Furthermore, the labor market participation two years prior to birth is not influenced by the (planned) pregnancy. ${ }^{2}$ Maternal labor supply before child birth thus works as an indicator for labor market attachment. We expect the working hours of the mother before child birth to be strongly correlated to actual working hours, as both reflect the attitudes and working preferences of the woman. Several studies have shown that positive state dependence is likely to occur for both, the decision to return itself and the hours of labor supplied (e.g. Geyer and Steiner, 2007; Haan, 2005). Regarding the second condition, we assume that the working time two years before child birth does not influence current child care attendance through other channels than actual working hours. As we want to disentangle the simultaneity between the decision to work and the decision to use child care, former working hours do the job, as the decision is taken long before the decision for child care. However, education of the mother might affect both, former and current labor market supply. This is taken into account by inclusion of the years of education of the mother in the regression.

It is assumed that the error terms of equation (1) and (2) $(u, v)$ are bivariate normally distributed with zero mean, a correlation $\rho$ and variances 1 and $\sigma_{v}^{2}$, respectively (see Wooldridge, 2002; Winkelmann and Boes, 2006). ${ }^{3}$ Under the joint normal distribution of $(u, v)$ with $\operatorname{var}(u)=1$ follows: $u=\theta v+\epsilon$, where $\theta=\frac{\eta}{\tau^{2}}, \eta=\operatorname{cov}(u, v), \tau^{2}=\operatorname{var}(v)$ and $\epsilon$ is independent of $z$ in equation (2) and $v$ and therefore of mother's working time, with $z \alpha=\alpha_{0}+\alpha_{1}$ worktime $_{t-2}+\alpha_{2}$ educm $+\alpha_{3}$ sibl $+\alpha_{4}$ age $_{c}+\alpha_{5}$ agem $+\alpha_{6}$ nat + $\alpha_{7}$ citysize $+\alpha_{8}$ state $+\alpha_{9}$ years. Because of the joint normal distribution of $(u, v) \epsilon$ is also normal distributed with $E[\epsilon]=0, \operatorname{var}(\epsilon)=\operatorname{var}(u)-\frac{\eta}{\tau^{2}}=1-\rho^{2}$, and $\rho=\operatorname{corr}(v, u)$.

So estimation equation (1) can be rewritten conditional on $v$ as follows:

$$
\begin{aligned}
y^{*}= & \beta_{0}+\beta_{1} \text { worktime }+\beta_{2} \text { educm }+\beta_{3} \text { sibl }+\beta_{4} \text { age } e_{c}+\beta_{5} \text { agem } \\
& +\beta_{6} \text { nat }+\beta_{7} \text { citysize }+\beta_{8} \text { state }+\beta_{9} \text { years }+\theta_{1} v+\epsilon
\end{aligned}
$$

\footnotetext{
${ }^{2}$ Using the working time three years before birth yields to similar results.

${ }^{3}$ Note that there is no endogeneity problem if $u$ and $v$ are independent.
} 


$$
\epsilon \mid z, \text { worktime, } v \sim N\left(0,1-\rho^{2}\right)
$$

where $v$ is not known, but we can replace it by an estimate. So in the first step we estimate equation (2) by OLS to get the residuals $\hat{v}$. In step two we estimate a probit model of childcare on working time (equation (3)), $z_{1}$ with $z_{1} \beta=\beta_{0}+\beta_{2}$ educm $+\beta_{3}$ sibl + $\beta_{4}$ age $e_{c}+\beta_{5}$ agem $+\beta_{6}$ nat $+\beta_{7}$ citysize $+\beta_{8}$ state $+\beta_{9}$ years and $\hat{v}$ to obtain consistent estimators of the probit equation by Maximum Likelihood.

\section{$3 \quad$ Data and descriptive statistics}

The analysis is based on longitudinal data from the German Socio Economic Panel Study (GSOEP) at the German Institute for Economic Research (DIW), Berlin. The GSOEP is an annual representative sample beginning in 1984 of approximately 12,000 private households whereof we use the years 1989 to 2006 because there are not enough observations in the years before. While drawing our sample on the child level, we use information on household characteristics, educational background and labor market participation of the parents as well as information concerning institutional child care. As child care supply and habits in using child care are still significantly different in the five new federal states and the number of observations is rather small we exclude East Germany from our sample. To control for the fact that once the decision to attend child care is made, there is high probability of continued kindergarten participation, we use clustered and robust standard errors in our pooled sample on the child level. Through this clustering we allow for serial correlation within a cluster but not between different clusters.

Restricting the sample We would expect that mothers' decisions to work after the first-born child differ from the decisions to work after the second born child. For example, it is more likely that mothers reenter the labor market, if they have only one child in comparison to mothers with at least one child. To disentangle the "real" labor market decision from the number of children living in the household, our sample contains only the first-born child. In restricting the sample, we are able to estimate a much stronger first stage and obtain a more precisely estimated second stage coefficient. The sample contains 2,970 observations for first born children aged three to seven years.

Child care participation 1984-2006 Our analysis is carried out using participation in institutional child care ("Kinderkrippe" or "Kindergarten") as dependent variable. We focus on children between three and seven years. We do not separately analyze zero to two year olds (attending "Kinderkrippe") because there is only little variation in child care attendance within this sample (only 2.2 percent of children under 3 years attend "Kinderkrippe"). Two thirds of the children aged three to seven are attending institutional 
Figure 1: Share of mothers working by first child's age

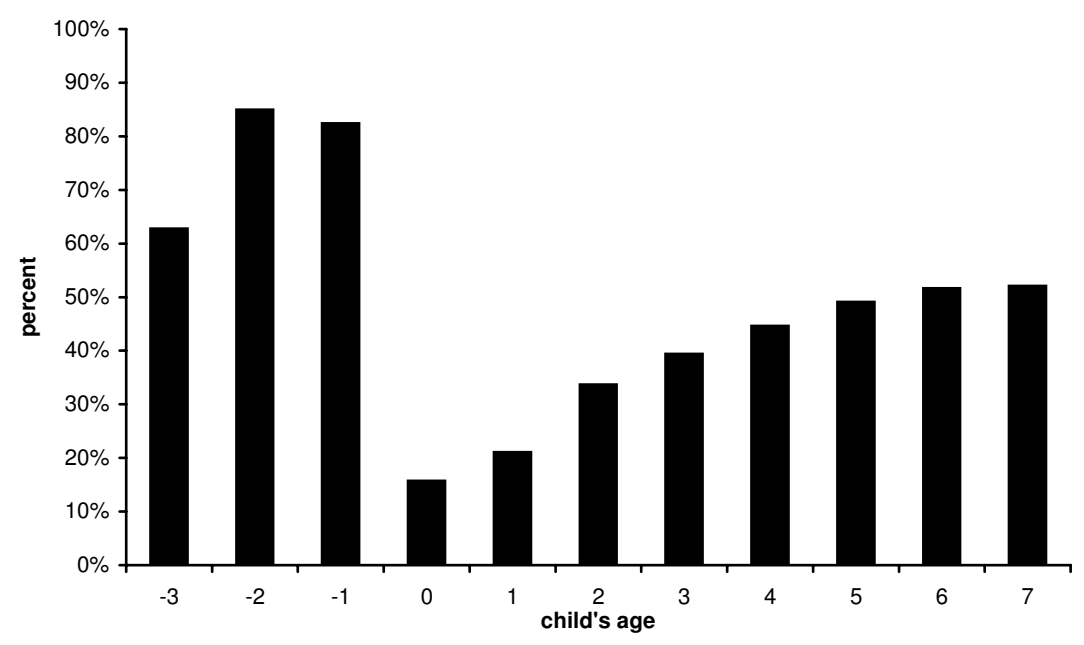

Data Source: Sample drawn from the GSOEP 1989-2006, 2.970 observations. Own calculations. Note: Values of child's age below zero indicate the years before birth of the first child.

child care, ranging from 15 percent for the three year olds to almost 90 percent for the elder children. Summary statistics on our sample are displayed in Table 1. Here, the share of mothers not working two years before birth of their first child is 15 percent, and is rising to 85 percent in the year after birth. With growing age of the child, the share of non-working mothers is diminishing until 48 percent at age seven (see Figure 1). In one of two cases the child has a younger sibling. Three quarters of the sample are children of parents with German nationality. The over-representation of immigrants in the sample is due to oversampling of foreigners in the GSOEP. We observe 10 percent single-parents in our sample.

Figure 2 displays the development of child care attendance over the last 20 years and compares GSOEP data to official census data. The GSOEP data only slightly differs from representative data (Statistisches Bundesamt, 1984-2004). Furthermore, both data show an increase in participation rates of three to seven year olds from 1996 on. ${ }^{4}$

In our analysis the actual weekly working time of the mother is our main variable of interest. We use the actual working time rather than contractual working time as the last does not reflect the real time the mother has left for her child. Neither in mothers' actual working time nor in their desired working time we observe structural changes. Nevertheless the two variables stay close to each other over the years (see Figure 3). The correlation coefficient between these two variables is 0.90 and a t-test yields no significant difference between mothers' desired and actual working time. We use this as an indicator that there is no problem of child care availability. Another implication out of this correlation is that there are minimal labor market restrictions for mothers.

\footnotetext{
${ }^{4}$ This could be a result of the policy change in the year 1996, where the legal claim on a child care slot was introduced. We observe an increase from 62 percent (1996) to 80 percent (2006) in the use of kindergarten for the relevant age group.
} 
Table 1: Summary statistics

\begin{tabular}{lrrrr}
\hline \hline \multicolumn{1}{c}{ Variable } & Mean & Std. Dev. & Min. & Max. \\
\hline CHILd CARE ATTENDANCE & 0.67 & 0.47 & 0 & 1 \\
WEEKLY WORKING HOURS MOTHER & 10.99 & 14.72 & 0 & 80 \\
SHARE OF MOTHERS WORKING & 0.46 & & & \\
SHARE OF MOTHERS WORKING BEFORE BIRTH & 0.85 & & & \\
EDUCATION MOTHER (IN YEARS) & 11.68 & 2.44 & 7 & 18 \\
CHILD'S AGE 3 & 0.26 & 0.44 & 0 & 1 \\
CHILD'S AGE 4 & 0.24 & 0.43 & 0 & 1 \\
CHILD'S AGE 5 & 0.22 & 0.41 & 0 & 1 \\
CHILD'S AGE 6 & 0.20 & 0.40 & 0 & 1 \\
CHILD'S AGE 7 & 0.08 & 0.27 & 0 & 1 \\
SIBLINGS & 0.51 & 0.50 & 0 & 1 \\
MOTHER'S AGE & 31.73 & 4.49 & 22 & 54 \\
SINGLE PARENT & 0.10 & 0.30 & 0 & 1 \\
(BOTH) PARENT(S) GERMAN & 0.77 & 0.42 & 0 & 1 \\
CITY SIZE & 4.12 & 1.73 & 1 & 7 \\
\hline \hline
\end{tabular}

Data Source: Sample drawn from the GSOEP 1989-2006, 2.970 observations. Own calculations.

Figure 2: Children in institutional child care 1984-2006: GSOEP and Mikrozensus

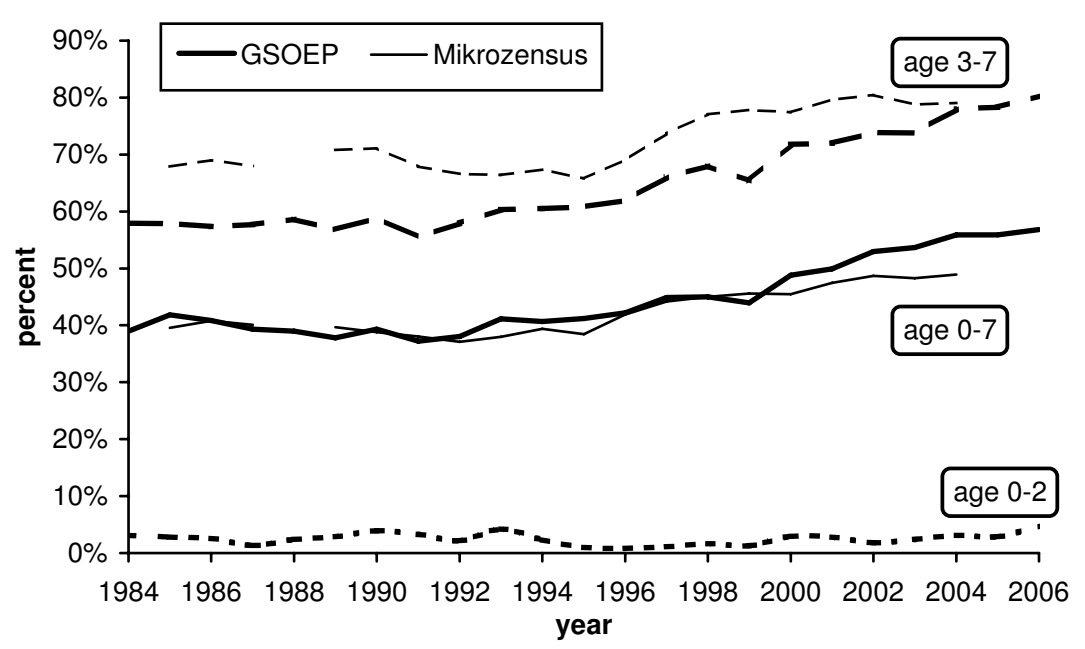

Data Source: GSOEP 1984-2006, Mikrozensus 1984-2004 (missing information for the years 1984, 1988, 2005 and 2006); own calculations. 
Figure 3: Desired vs actual working time of mothers (in means) 1989-2006

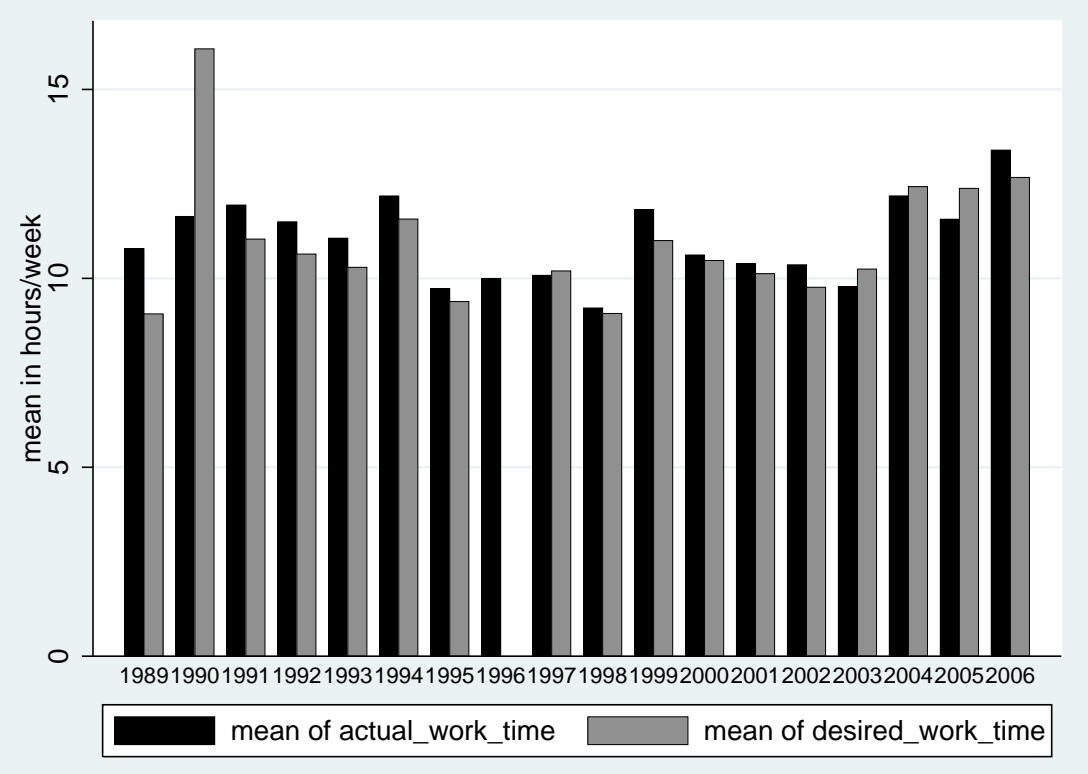

Data Source: Sample drawn from the GSOEP 1989-2006, 2.970 observations. Data for desired missing in 1996. Own calculations.

Note: Mothers with working time equal to zero are included. Only mothers of children aged three to seven are included.

Concerning the instrumental variable, the actual working hours of the mother two years before birth of the first child, we observe a significant correlation of 0.13 with the actual working hours. We observe variation in the working hours before birth (see Figure A.1 in the appendix) and no considerable state-dependence between the decision to work before and after birth of the first-born child. Using a dummy variable (worked/ worked not) instead of the continuous variable as instrument did not change the results. 


\section{Results}

We estimate the determinants of the decision to use institutional child care for the sample of first-born children living in West Germany that are between three and seven years old. The estimation results of the probit model (Probit) and the binary response model with one continuous and endogenous regressor (IV-Probit) are shown in Table 2. Our main result is the positive and significant impact of the mother's actual working time on the probability of the child to attend institutional child care. If the working time of the mother rises by ten hours a week, the probability of Kindergarten attendance increases by eleven percentage points. More interestingly, we observe an under-estimation of this effect if we do not control for simultaneity in the decision process. In the binary response model with one continuous endogenous regressor (IV-Probit), the influence of the hours worked is more than twice as large as the estimates predicted by the probit model. Intuitively, we would have expected an upward bias as we expect the participation in child care to rise with rising working hours of the mother and vice versa. The observed downward bias might be caused by omitted variables, which are negatively correlated with the working time. Such a variable could be an influence that we would describe as "social norms" or "social expectations". We define these as 1) work ethic (working as such is good and socially preferred), 2) mothers should stay at home, if their children are not yet attending school, and 3) children should attend institutional child care from the beginning of age three on. If these social norms exist in West Germany, it would imply that even if the mothers do not necessarily participate in the labor market, their children are still likely to attend institutional child care. And this is indeed what we observe. 32 percent of the children are attending institutional child care while their mothers are not working.

There are several studies in the literature which support our explanation. First, Wernhart and Neuwirth (2005) perform a European comparison based on data from the International Social Survey Programme (ISSP) from 2002. Their results show that more than half of the West Germans think that preschool children suffer if their mothers work. With this rate, West Germany ranks under the first five countries in Europe. Furthermore, almost 90 percent of the Germans think, women should work when married but not when they have children. When having children under age 7 , mothers should stay at home in the view of 50 percent of the West Germans. Only Poland, the United Kingdom and Slovakia have higher rates on this issue. Secondly, when studying the life satisfaction of mothers results point in a somewhat similar direction. E.g. Holst and Trzcinski (2003) show that German mothers who work part-time are the most, mothers who work full-time are the least satisfied with their lives.

Furthermore, we find several positive and significant determinants of the probability to give a child into institutional child care and can thus confirm most of the results of other studies (Spiess, Buechel, and Frick, 2002; Kreyenfeld, 2004). We observe no significant im- 
Table 2: Kindergarten - Average Marginal Effects

\begin{tabular}{|c|c|c|}
\hline first-born children (3-7 years) & Probit & IV-Probit \\
\hline WEEKLY WORKING HOURS MOTHER & $\begin{array}{l}0.004^{* * *} \\
(0.001)\end{array}$ & $\begin{array}{l}0.011^{* *} \\
(0.014)\end{array}$ \\
\hline EDUCATION MOTHER (IN YEARS) & $\begin{array}{l}0.012^{* *} \\
(0.005)\end{array}$ & $\begin{array}{r}0.005 \\
(0.024)\end{array}$ \\
\hline SIBLINGS & $\begin{array}{r}0.029 \\
(0.025)\end{array}$ & $\begin{array}{c}0.101^{*} \\
(0.172)\end{array}$ \\
\hline CHILD'S AGE 4 & $\begin{array}{l}0.317^{* * *} \\
(0.016)\end{array}$ & $\begin{array}{l}0.305^{* * *} \\
(0.152)\end{array}$ \\
\hline CHILD'S AGE 5 & $\begin{array}{l}0.428^{* * *} \\
(0.016)\end{array}$ & $\begin{array}{l}0.418^{* * *} \\
(0.256)\end{array}$ \\
\hline CHILD'S AGE 6 & $\begin{array}{l}0.451^{* * *} \\
(0.015)\end{array}$ & $\begin{array}{l}0.441^{* * *} \\
(0.321)\end{array}$ \\
\hline CHILD'S AGE 7 & $\begin{array}{l}0.300^{* * *} \\
(0.014)\end{array}$ & $\begin{array}{l}0.301^{* * *} \\
(0.297)\end{array}$ \\
\hline MOTHER'S AGE & $\begin{array}{r}0.005 \\
(0.003)\end{array}$ & $\begin{array}{r}0.005 \\
(0.010)\end{array}$ \\
\hline SINGLE PARENT & $\begin{array}{l}0.084^{* * *} \\
(0.029)\end{array}$ & $\begin{array}{r}0.067 \\
(0.134)\end{array}$ \\
\hline (BOTH) PARENT(s) GERMAN & $\begin{array}{l}0.104^{* * *} \\
(0.031)\end{array}$ & $\begin{array}{l}0.127^{* * *} \\
(0.097)\end{array}$ \\
\hline CITY SIZE & $\begin{array}{c}0.014^{*} \\
(0.007)\end{array}$ & $\begin{array}{c}0.013^{*} \\
(0.024)\end{array}$ \\
\hline $\begin{array}{l}\text { LAENDER DUMMIES } \\
\text { YEAR DUMMIES }\end{array}$ & $\begin{array}{l}\text { yes } \\
\text { yes }\end{array}$ & $\begin{array}{l}\text { yes } \\
\text { yes }\end{array}$ \\
\hline $\mathrm{N}$ & 2,970 & 2,970 \\
\hline$\chi^{2}$ & $1174.24^{* * *}$ & $1218.56^{* * *}$ \\
\hline
\end{tabular}

Data Source: GSOEP 1989-2006. Std. Dev. in brackets. Own calculations.

Note: See first-stage regression in the appendix, Table A.2.

Significance levels: $\quad *: 10 \% \quad * *: 5 \% \quad * * *: 1 \%$. 
pact of the education of the mother on the probability of the child attending institutional child $_{\text {care. }}{ }^{5}$

If the child has siblings, the probability of attending kindergarten rises. At first, we would expect caring parents more frequently staying at home if they have more young children. But our result supports the idea that parents with more young children seek for institutional child care to have time for the babies and housework. In addition, in the institutional setting, the probability of getting a child care slot rises with the number of children a family has. The age dummies are all significant and positive implying that the probability of a child attending kindergarten is rising with age. This is not surprising as descriptive statistics show that the attendance rates increases from 17 percent at age three to 93 percent at age seven in the sample.

There is no significant impact if one parent is raising the child alone. We conclude that single-parents are not different in their demand for child care, respectively that the WORKING HOURS variable catches this difference already. There does not seem to be a substantial difference between households with two parents or other relatives (such as grandparents) and single-parent households. If both parents or the single-parent are German, the probability of sending the child to kindergarten rises. The kindergarten attendance seems to be more frequent for Germans. This could be due to different cultural settings and as well to the higher number of persons in immigrant households providing more possibilities for informal child care. Children coming from larger cities are more frequently attending kindergarten. This last fact is not surprising as the supply of institutional child care slots increases with city size (Kreyenfeld, 2004). Although, the 1996 law assures a half-time slot for all children from age three on, parents in need for a fulltime slot might face supply side restrictions, especially in rural areas. Furthermore, the labor attachment of mothers is higher in bigger cities and we suppose that informal child care settings are more frequent in rural areas. Year dummies control for year-specific effects in the pooled sample, as well as Laender dummies control for differences between the ten West German federal states. ${ }^{6}$ We would expect that year effects capture supply side restrictions of institutional child care as well as to some extent differences across fee structures. $^{7}$

\footnotetext{
${ }^{5}$ Including the education time of the father in addition to the mother's education time in the estimation results in a "transfer" of the mother's education impact on the father's coefficient. It seems as if fathers' education is in general higher than mothers' and therefore stronger correlated with the kindergarten decision.

${ }^{6}$ Rhineland-Palatine and the Saarland are captured in one dummy variable for number of observation reasons.

${ }^{7}$ Including income variables, such as the equivalence income of the household or the hourly wage of the mother do not give any significant impact. The same is true for employment categories (blue-collar, white-collar, civil servant and self-employed) and education categories (instead of education in years).
} 


\section{Conclusion}

In West Germany, child care use for children aged three to seven is still low in comparison to other Western European countries. Therefore politically it is very interesting to understand the determinants of institutional child care. The aim of the study is thus to investigate the main factors that drive the decision for institutional child care in West Germany using an estimation approach which explicitly accounts for the simultaneity in mothers' decision to work and the decision for child care. Our results show that the labor market status of the mother is an important predictor for the fact whether the child is in institutional care or not. First-born children living in Western Germany have a higher probability to attend institutional care if their mothers increase their actual weekly working time. Parents might thus consider child care as an alternative when the mother wants or needs to work. Estimating the probability to attend child care without accounting for the simultaneity in the work and care decisions leads to a substantial underestimation of the effect. In the binary response model with one continuous endogenous regressor, the influence of the hours worked is more than twice as large as the estimates predicted by the probit-model. This downward bias is not expected when taking account of simultaneity. We conclude that it could result from omitted variables reflecting social norms and being negatively correlated with the child care choice. This implies that even if the mothers do not necessarily participate in the labor market, their children are still likely to attend institutional child care, e.g. for educational reasons. We indeed observe 32 percent of the children attending institutional child care while their mothers are not working. Moreover, immigrants seem more often to rely on inner-familial child care arrangements. This can be due to the larger number of adults in the household. But it might partly be caused by lower financial resources or reluctance against preschool education for cultural reasons.

As our analysis is limited to first-born children aged between three and seven years several questions are left for future research. First, it might be interesting to study how a mother's decision to work affects the decision of institutional child care for children under age three. Due to the low participation rates for West Germany, research related to this issue could be undertaken using the data for East Germany available in the GSOEP. More research on the attendance of different types of out-of home care and its effects on different families, e.g. families with migration background might be a second interesting topic. Due to data limitations this research must also be postponed. 


\section{References}

Bender, S., A. Kohlmann, and S. Lang (2003): "Women, Work, and Motherhood: Changing Employment Penalties for Motherhood in West Germany after 1945 - A Comparative Analysis of Cohorts Born in 1934-1971," MPIDR Working Paper WP 2003-006.

Bien, W., T. Rauschenbach, and B. Riedel (eds.) (2006): Wer betreut Deutschlands Kinder? Beltz, Weinheim.

Buechel, F., And C. K. SpIEss (2002): "Form der Kinderbetreuung und Arbeitsmarktverhalten von Müttern in West- und Ost-Deutschland," Gutachten im Auftrag des Bundesministeriums für Familie, Senioren, Frauen und Jugend.

Del Boca, D., M. Locatelli, and D. Vuri (2005): "Child Care Choices by Working Mothers: The Case of Italy," Review of Economics of the Household, 3(4), 453-477.

Djurdjevic, D. (2005): "Women's Labour Supply After Child Birth - An Empirical Analysis for Switzerland," Darmstadt Discussion Papers in Economis No. 144.

Geyer, J., And V. Steiner (2007): "Short-Run and Long-Term Effects of Childbirth on Mothers' Employment and Working Hours Across Institutional Regimes: An Empirical Analysis Based on the European Community Household Panel," IZA Discussion Paper No. 2693.

HaAn, P. (2005): "State Dependence and Female Labor Supply in Germany - The Extensive and the Intensive Margin," DIW Discussion Paper No. 538.

Hank, K., and M. Kreyenfeld (2003): "A Multilevel Analysis of Child Care and Women's Fertility Decisions in Western Germany," Journal of Marriage and Family, $65(3), 584-596$.

Henly, J. R., And S. Lyons (2000): "The Negotiation of Child Care and Employment Demands Among Low-Income Parents," Journal of Social Issues, 56(4), 683-706.

Holst, E., And E. Trzcinski (2003): "High Satisfaction Among Mothers Who Work Part-time," Economic Bulletin, 40(10).

Johansen, A. S., A. Leibowitz, and L. J. Waite (1996): "The Importance of ChildCare Characteristics to Choice of Care," Journal of Marriage and the Family, 58(3), 759-772.

Kreyenfeld, M. (2004): "Sozialstruktur und Kinderbetreuung," MPIDR Working Paper 2004-009, Rostock.

Michalopoulos, C., and P. K. Robins (2002): "Employment and Child-Care Choices of Single-Parent Families in Canada and the United States," Journal of Population Economics, 15(3), 465-493.

OECD (2006): Starting Strong II -Early Childhood Education and Care. Organization for Economic Collaboration and Development, Paris. 
OndRich, J., AND C. K. SpIEss (1998): "Care of Children in a Low Fertility Setting: Transitions Between Home and Market Care for Pre-school Children in Germany," Population Studies, 52(1), 35-48.

Peyton, V., A. Jacobs, M. O'Brien, and C. Roy (2001): "Reasons for Choosing Child Care: Associations with Family Factors, Quality, and Satisfaction," Early Childhood Research Quarterly, 16(2), 191-218.

Pungello, E., And B. Kurtz-Costes (1999): "Why and How Working Women Choose Child Care: A Review with a Focus on Infancy," Developmental Review, 19(1), 31-96.

SEO, S. (2003): "Early Child Care Choices: a Theoretical Model and Research Implications," Early Child Development and Care, 173(6), 637-650.

Spiess, C. K., F. Buechel, And J. Frick (2002): "Kinderbetreuung in West- und Ostdeutschland: Sozio-ökonomischer Hintergrund entscheidend," Wochenbericht des DIW, 31/02.

Statistisches Bundesamt (1984-2004): "Mikrozensus 1984-2004," .

Wernhart, G., and N. Neuwirth (2005): "Geschlechterrollenwandel und Familienwerte (1988-2002)," Austrian Institute for Family Studies, Working Paper No. 54.

Winkelmann, R., And S. Boes (2006): Analysis of Microdata. Springer, Berlin.

Wooldridge, J. M. (2002): Econometric Analysis of Cross-Section and Panel Data. MIT Press, Cambridge. 
Table A.1: Variable Definition

\begin{tabular}{|c|c|c|c|}
\hline & Variable & Type* & Definition \\
\hline \multicolumn{4}{|c|}{ Endogenous variable } \\
\hline & CHILD CARE & $0 / 1$ & 1 if child attends institutional child care \\
\hline \multicolumn{4}{|c|}{ Explanatory variables } \\
\hline \multirow{14}{*}{$\begin{array}{l}\text { WEEKLY WORH } \\
\text { EDUCATION }\end{array}$} & KING HOURS MOTHER & $\mathrm{c}$ & actual working time of the mother in hours per week \\
\hline & MOTHER (IN YEARS) & $\mathrm{c}$ & amount of education of the mother in years \\
\hline & SIBLINGS & $0 / 1$ & 1 if siblings live in the household \\
\hline & CHILD'S AGE 3 & $0 / 1$ & 1 if the child is 3 years old \\
\hline & CHILD'S AGE 4 & $0 / 1$ & 1 if the child is 4 years old \\
\hline & CHILD'S AGE 5 & $0 / 1$ & 1 if the child is 5 years old \\
\hline & CHILD'S AGE 6 & $0 / 1$ & 1 if the child is 6 years old \\
\hline & CHILD'S AGE 7 & $0 / 1$ & 1 if the child is 7 years old \\
\hline & MOTHER'S AGE & $\mathrm{c}$ & age of the mother in years \\
\hline & SINGLE PARENT & $0 / 1$ & 1 if the child lives in a single-parent household \\
\hline & PARENT(S) GERMAN & $0 / 1$ & $\begin{array}{l}1 \text { if nationality of both parents is German } \\
\text { or single-parent is German }\end{array}$ \\
\hline & CITY SIZE & $\mathrm{c}$ & $\begin{array}{l}\text { size of the municipality the household lives in } \\
\text { from } 1=\text { less than } 2,000 \text { to } 7=\text { more than } 500,000\end{array}$ \\
\hline & REGIONAL DUMMIES & $0 / 1$ & $\begin{array}{l}\text { Laender in West Germany, } \\
\text { ref.: North-Rhine Westfalia }\end{array}$ \\
\hline & YR1990 TO YR2006 & $0 / 1$ & year dummies for 1990 to 2006, ref.: 1989 \\
\hline
\end{tabular}

Notes: ${ }^{*} \mathrm{c}=$ continuous variable 
Table A.2: IV-Probit - first stage regression for actual weekly working hours of mother

\begin{tabular}{lc}
\hline \hline instrument & \\
\hline WEEKLY WORKING HOURS MOTHER BEFORE BIRTH & $0.133^{* * *}$ \\
exogenous variables & $(0.211)$ \\
\hline EDUCATION MOTHER (IN YEARS) & $1.029^{* * *}$ \\
SIBLINGS & $(0.805)$ \\
& $-10.812^{* * *}$ \\
CHILD'S AGE 4 & $(0.516)$ \\
& $3.333^{* * *}$ \\
CHILD'S AGE 5 & $(0.628)$ \\
& $5.716^{* * *}$ \\
CHILD'S AGE 6 & $(0.718)$ \\
& $6.983^{* * *}$ \\
CHILD'S AGE 7 & $(1.086)$ \\
MOTHER'S AGE & $7.844^{* * *}$ \\
& $(0.109)$ \\
SINGLE PARENT & -0.025 \\
(BOTH) PARENT(S) GERMAN & $(1.362)$ \\
CITY SIZE & $3.789^{* * *}$ \\
YEAENDER DUMMIES & $(1.119)$ \\
\hline N & $-4.246^{* * *}$ \\
\hline \hline
\end{tabular}

Data Source: GSOEP 1989-2006. Std. Dev. in brackets. Own calculations.

Significance levels: $\quad{ }^{*}: 10 \% \quad{ }^{* *}: 5 \% \quad{ }^{* * *}: 1 \%$. 
Figure A.1: Distribution of the actual working hours of the mother two years before birth of the first child

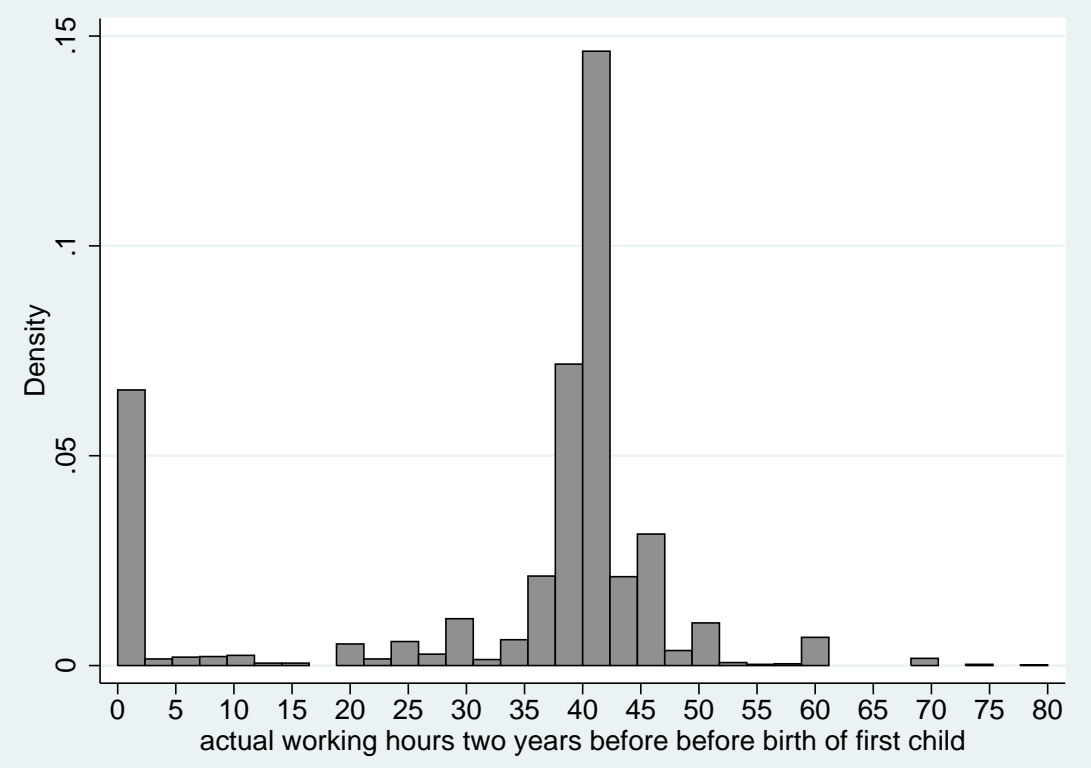

Data Source: Sample drawn from the GSOEP 1989-2006, 2.970 observations. Own calculations. 